\title{
Reduction of Salivary Streptococcus mutans Colonies in Children After Rinsing with $2.5 \%$ Green Tea Solution
}

\author{
Fajriani $^{1}$, Jennifer N. Andriani² \\ ${ }^{1}$ Department of Pediatric Dentistry, Faculty of Dentistry, University of Hasanuddin, Makassar 90245, South Sulawesi, \\ Indonesia \\ ${ }^{2}$ Undergraduate Program, Faculty of Dentistry, University of Hasanuddin, Makassar 90245, South Sulawesi, \\ Indonesia \\ Correspondence e-mail to: fajriani_fkg@yahoo.com
}

\begin{abstract}
Dental caries is a problematic area in pediatric dentistry, with Streptococcus mutans as the dominant bacterial cause. Green tea solution and chlorhexidine were effective in reducing the number of Streptococcus mutans. But study about the differences of these two materials has not been done. Objective: The aim of this study was to determine differences in the effectiveness of rinsing with $0.2 \%$ chlorhexidine and $2.5 \%$ green tea solution in reducing the number of Streptococcus mutans. Methods: This study is quase experimental study with cross-over design. Thirty children aged 6-12 years with poor OHI-S index were participated. Samples of saliva were taken respectively before rinsing for 3 seconds with $0.2 \%$ chlorhexidine solution and a solution of $2.5 \%$ green tea and 15 minutes followed 30 minutes after rinsing intervention. Saliva samples were taken to the laboratory then the number of Streptococcus mutans count were evaluated. The statistical analysis were performed by SPSS version 18.0 with ANOVA, t-paired and LSD test. Results: ANOVA test result showed that the decrease generated by each mouthwash is a significant reduction. T-paired test result showed that there is no difference in the number of Streptococcus mutans colonies significantly between chlorhexidine and green tea solution at 15 minutes dan 30 minutes after rinsing. Conclusion: There is no significant difference between chlorhexidine and green tea solution in reducing the number of Streptococcus mutans.
\end{abstract}

\begin{abstract}
ABSTRAK
Pengurangan koloni Streptococcus mutans saliva pada anak setelah kumur larutan teh hijau 2,5\%. Karies merupakan masalah dalam kedokteran gigi anak, dengan Streptococcus mutans sebagai bakteri dominan penyebab karies. Larutan teh hijau dan klorheksidin efektif mengurangi jumlah koloni dari Streptococcus .mutans. Namun belum diteliti lebih lanjut mengenai perbedaan efektivitas kedua bahan tersebut. Tujuan: Penelitian ini bertujuan untuk mengetahui perbedaan efektivitas berkumur dengan klorheksidin 0,2\% dan larutan teh hijau 2,5\% dalam menurunkan jumlah koloni Streptococcus mutans. Metode: Penelitian ini bersifat eksperimental semu dengan desain cross over. Jumlah sampel sebanyak 30 orang anak-anak berusia 6-12 tahun dengan indeks OHI-S kurang. Sampel saliva diambil masing-masing sebelum berkumur selama 3 detik dengan larutan klorheksidin 0,2\% dan larutan teh hijau 2,5\% dan 15 menit dilanjutkan 30 menit setelah berkumur. Sampel saliva dibawa ke laboratorium kemudian dilakukan perhitungan jumlah koloni bakteri Streptococcus mutans. Data dianalisis dengan menggunakan program SPSS versi 18.0 dengan uji ANOVA t-berpasangan, dan uji beda lanjut (LSD). Hasil: Uji ANOVA menunjukkan bahwa penurunan yang dihasilkan oleh masing-masing obat kumur merupakan penurunan yang signifikan. Hasil uji t-berpasangan menunjukkan tidak terdapat perbedaan jumlah koloni Streptococcus mutans yang signifikan antara klorheksidin dan larutan teh hijau pada interval waktu 15 menit dan 30 menit setelah berkumur. Simpulan: Tidak ada perbedaan yang bermakna antara klorheksidin dan larutan teh hijau terhadap jumlah koloni Streptococcus mutans.
\end{abstract}

Key words: chlorhexidine, green tea, Streptococcus mutans 


\section{PENDAHULUAN}

Sampai saat ini, karies gigi masih menjadi masalah utama dalam bidang kedokteran gigi dan menjadi salah satu penyakit infeksi yang paling umum pada anak. Karies merupakan suatu penyakit infeksi mikrobiologi pada gigi yang menyebabkan perubahan secara lokal dan kerusakan jaringan keras gigi. Adanya kavitas/ lubang pada gigi merupakan tanda adanya infeksi bakteri. Karies memiliki etiologi multifaktorial seperti substrat, mikroorganisme, pejamu, dan waktu yang mengakibatkan demineralisasi email. Menurut laporan Pengurus Besar Persatuan Dokter Gigi Indonesia (PDGI) pada tahun 2000 yang dikutip oleh Tedjosasongko, prevalensi karies gigi pada anak-anak di Indonesia masih sangat tinggi dibandingkan dengan negara berkembang lainnya. Menurut Riset Kesehatan Dasar (RISKESDAS) pada tahun 2007 yang dikutip oleh Darwita, prevalensi masalah kesehatan gigi dan mulut pada murid sekolah dasar mencapai $72,1 \% .^{1-3}$

Salah satu mikroba patogen penyebab karies yang banyak ditemukan dalam biofilm kariogenik atau plak adalah Streptococcus mutans. Telah banyak penelitian yang membuktikan adanya hubungan yang erat antara jumlah koloni bakteri Streptococcus mutans pada saliva dengan prevalensi karies gigi. Anak-anak dengan tingkat karies tinggi juga mengalami peningkatan jumlah koloni Streptococcus mutans. ${ }^{4}$

Ada banyak cara menurunkan jumlah koloni bakteri dalam rongga mulut. Salah satunya yaitu dengan penggunaan obat kumur. Di Indonesia, salah satu contoh obat kumur yang sangat mudah kita peroleh di pasaran yaitu klorheksidin. Klorheksidin merupakan agen antimikroba berspektrum luas dan memiliki efek bakterisidal terhadap semua jenis mikroba, termasuk bakteri, jamur, dan virus. Klorheksidin terbukti dapat menghambat pembentukan plak, mengurangi inflamasi gingiva dan mencegah karies gigi. Selanjutnya, klorheksidin $0,2 \%$ sebanyak $10 \mathrm{ml}$ sekali sehari dapat mereduksi koloni Streptococcus mutans 30-50\%. Klorheksidin merupakan obat kumur yang efektif mengurangi jumlah Streptococcus mutans. Namun terdapat kekurangan klorheksidin, karena ternyata bahan ini merupakan bahan kimia yang dapat menyebabkan rasa tidak enak dan menyebabkan stain pada gigi. ${ }^{5-7}$

Seiring dengan berjalannya waktu, banyak penelitian telah dilakukan dan ditemukan tanaman herbal yang memiliki potensi besar sebagai obat pencegah penyakit gigi dan mulut, misalnya teh hijau. Teh hijau dapat digunakan sebagai obat kumur untuk menghambat pembentukan plak serta mencegah karies gigi, penyakit periodontal, halitosis, dan kanker mulut. Selain itu, teh hijau juga dapat mencegah penyakit kardiovaskular, stroke, obesitas, dan kanker. ${ }^{8,9}$

Komponen bioaktif teh hijau mampu mempengaruhi proses terjadinya karies gigi dengan menghambat proliferasi, produksi asam, metabolisme, dan aktivitas enzim glukosiltransferase (GTF) dari Streptococcus mutans dan plak. Penelitian sebelumnya menunjukkan bahwa konsumsi teh hijau dapat menghambat deposisi plak dan mengurangi tingkat koloni Streptococcus mutans dan Lactobacillus pada plak dan saliva. ${ }^{6,7}$ Berdasarkan penelitian lainnya, katekin dengan konsentrasi 0,125-1\% menunjukkan penurunan jumlah bakteri, pembentukan plak dan jumlah total protein bakteri dan glucan ekstraselular, dan daya hambat minimal teh hijau terhadap Streptococcus mutans adalah 2,5\%, meskipun pada konsentrasi $1 \%$ telah dapat menghambat pertumbuhan Streptococcus mutans. ${ }^{8-10}$

Berdasarkan penelitian sebelumnya, teh hijau kemasan merk Tong $\mathrm{Tji}^{\circledR}$ memiliki kadar polifenol tertinggi dari beberapa jenis teh hijau lainnya yang beredar di pasaran, oleh karena itu peneliti memutuskan menggunakan teh hijau kemasan ini sebagai subjek penelitian. ${ }^{10,13,14}$ Penelitian-penelitian yang pernah dilakukan sebelumnya menunjukkan bahwa larutan teh hijau dan klorheksidin efektif mengurangi jumlah koloni dari Streptococcus mutans..$^{4,711}$ Namun belum diteliti lebih lanjut mengenai perbedaan efektivitas kedua bahan tersebut. Berdasarkan pertimbangan ini, peneliti ingin mengetahui apakah larutan teh hijau memiliki efektivitas yang sama dengan klorheksidin atau berbeda dalam mengurangi jumlah koloni dari Streptococcus mutans.

\section{METODE}

\section{Subjek penelitian}

Penelitian ini merupakan penelitian eksperimental semu dengan desain penelitian cross over design yang dilaksanakan pada tanggal 22 Februari - 29 Maret 2013 di SD Inpres Universitas Hasanuddin dan Laboratorium Mikrobiologi Fakultas Kedokteran Universitas Hasanuddin. Subjek dipilih berdasarkan simple random sampling pada siswa SD Inpres Universitas Hasanuddin berusia 6-12 tahun. Diambil subjek berusia 6-12 tahun karena merupakan periode gigi bercampur dan tingkat kesadaran kebersihan mulut pada anak usia tersebut masih kurang. Jumlah subjek sebanyak 30 orang (20 laki-laki dan 10 perempuan). Karena penelitian ini menggunakan desain cross-over, maka total subjek adalah 60 orang. Setiap subjek diberi intervensi berkumur dengan klorheksidin $0,2 \%$ dan larutan teh hijau 2,5\%.

Pengukuran Oral Hygiene Index Simplified (OHI-S) Sebelum penelitian dilakukan, terlebih dahulu dilakukan pemeriksaan oral hygiene menggunakan indeks OHI-S pada calon subjek. Kriteria inklusi subjek penelitian adalah anak dengan indeks OHI-S yang kurang atau buruk dengan skor indeks 3,1-6,0, memiliki minimal empat gigi yang mengalami karies dan bersedia mengikuti prosedur penelitian. Subjek penelitian diminta untuk tidak makan dan minum 
selama minimal 2 jam sebelum prosedur penelitian dilakukan. Kriteria eksklusi penelitian adalah anak dengan penyakit autoimun atau penyakit sistemik lainnya, sedang mengonsumsi antibiotik dan tidak bersedia mengikuti prosedur penelitian. Penelitian ini dilakukan setelah mendapatkan rekomendasi persetujuan etik nomor: 041/H4.8.5.31/PP36KOMETIK/2010.

\section{Larutan teh hijau dan klorheksidin}

Larutan teh hijau 2,5\% dibuat dengan cara menyeduh 7,5g teh hijau merk Tong $\mathrm{Tji}^{\circledR}$ dengan aquades $300 \mathrm{ml}$ bersuhu $70-80^{\circ} \mathrm{C}$. Obat kumur klorheksidin $0,2 \%$ merupakan obat kumur paten merk Minosep ${ }^{\circledR}$ yang dijual di pasaran dengan konsentrasi $0,2 \%$.

Prosedur penelitian dimulai dengan mengambil saliva sebelum intervensi berkumur. Kemudian subjek diinstruksikan untuk berkumur dengan klorheksidin dan larutan teh hijau. Kedua bahan ini diberikan dengan periode wash-out 1 minggu. Subjek diinstruksikan untuk berkumur selama 30 detik dengan kuat, karena 30 detik merupakan merupakan waktu ideal untuk obat kumur dapat bekerja secara optimal. Selanjutnya, sampel kumur dibawa ke laboratorium untuk evaluasi jumlah koloni Streptococcus mutans. Sampel diencerkan hingga $10^{3}$, kemudian $0,05 \mathrm{ml}$ sampel diambil menggunakan senkelit sebanyak secara aseptik ke cawan petri berisi medium Glucose Nutrient Agar (GNA). Medium GNA ini mengandung glukosa yang dapat menyesuaikan keadaan yang menyerupai rongga mulut. Selanjutnya agar diinkubasi selama 24 jam pada inkubator dengan suhu $37^{\circ} \mathrm{C}$. Pengamatan bakteri dilakukan dengan menghitung jumlah koloni bakteri Streptococcus mutans menggunakan metode colony counter untuk mendapatkan Colony Forming Unit (CFU). Data dianalisis dan diuji secara statistik dengan uji t-berpasangan dan ANOVA dengan confidence interval 95\% menggunakan program SPSS 18.0.

\section{HASIL}

Tabel 1 menunjukkan distribusi karakteristik sampel penelitian yang seluruhnya berjumlah 30 orang. Akan tetapi, karena penelitian ini menggunakan desain crossover, maka jumlah sampel untuk perlakuan terhitung sebanyak 60 subyek sampel. Terlihat dari 30 orang ini, jumlah laki-laki lebih banyak dibanding perempuan, yaitu 20 laki-laki (66,7\%) dan 10 perempuan $(33,3 \%)$ dengan rata-rata usia berkisar 8 tahun. Diperoleh ratarata nilai kebersihan mulut sampel penelitian sebesar 3,70. Jumlah koloni Streptococcus mutans sebelum intervensi adalah 85,57 CFU/ml. Setelah intervensi klorheksidin pada menit ke 15 menjadi $43.80 \mathrm{CFU} /$ $\mathrm{ml}$ dan setelah menit ke 30 menurun hingga 14,47 CFU/ml; sedangkan pada kelompok teh hijau, menit menjadi 44,20 CFU/ml dan setelah 30 menit menjadi $17,50 \mathrm{CFU} / \mathrm{ml}$.
Tabel 1. Distribusi karakteristik sampel penelitian

\begin{tabular}{llll}
\hline $\begin{array}{l}\text { Karakteristik } \\
\text { sampel penelitian }\end{array}$ & $\begin{array}{l}\text { Frekuensi } \\
\text { (n) }\end{array}$ & $\begin{array}{l}\text { Persen } \\
\text { (\%) }\end{array}$ & Mean \pm SD \\
\hline Jenis Kelamin & & & \\
Laki-laki & 20 & 66,7 & \\
Perempuan & 10 & 33,3 & \\
Usia & & & $8,57 \pm 2,02$ \\
Nilai kebersihan & & $3,70 \pm 0,65$ \\
mulut (OHI-S) & & & \\
$\begin{array}{l}\text { Jumlah koloni } \\
\text { Streptococcus } \\
\text { mutans sebelum } \\
\text { (Pretest) }\end{array}$ & & $85,57 \pm 18,03$ \\
$\begin{array}{l}\text { Kelompok } \\
\text { klorheksidin }\end{array}$ & 30 & 100 & \\
$\quad \begin{array}{l}\text { Jumlah koloni 15 } \\
\text { menit (Posttest 1) }\end{array}$ & & $43,80 \pm 15,62$ \\
$\quad \begin{array}{l}\text { Jumlah koloni 30 } \\
\text { menit (Posttest 2) }\end{array}$ & & $14,47 \pm 8,85$ \\
$\begin{array}{l}\text { Kelompok larutan } \\
\text { teh hijau }\end{array}$ & & \\
$\quad \begin{array}{l}\text { Jumlah koloni 15 } \\
\text { menit (Posttest 1) }\end{array}$ & & \\
$\quad \begin{array}{l}\text { Jumlah koloni 30 } \\
\text { menit (Posttest 2) }\end{array}$ & & \\
\hline
\end{tabular}

Tabel 2. Perbedaan efektivitas masing-masing klorheksidin dan larutan teh hijau berdasarkan interval waktu

\begin{tabular}{|c|c|c|c|c|}
\hline \multirow{2}{*}{$\begin{array}{l}\text { Ke l o m p o k } \\
\text { Obat Kumur }\end{array}$} & CFU Pretest & $\begin{array}{l}\text { CFU } 15 \\
\text { menit }\end{array}$ & $\begin{array}{l}\text { CFU } 30 \\
\text { menit }\end{array}$ & \multirow{2}{*}{ p-value } \\
\hline & $M e a n \pm S D$ & $\begin{array}{l}\text { Mean } \pm \\
\text { SD }\end{array}$ & $\begin{array}{l}\text { Mean } \pm \\
\text { SD }\end{array}$ & \\
\hline Klorheksidin & $85,57 \pm 18,03$ & $\begin{array}{l}43,80 \pm \\
15,62\end{array}$ & $\begin{array}{l}14,47 \pm \\
8,85\end{array}$ & $0,000^{*}$ \\
\hline $\begin{array}{l}\text { Larutan teh } \\
\text { hijau }\end{array}$ & $85,57 \pm 18,03$ & $\begin{array}{l}44,20 \pm \\
14,24\end{array}$ & $\begin{array}{l}17,50 \pm \\
10,32\end{array}$ & $0,000^{*}$ \\
\hline
\end{tabular}

Tabel 2 memperlihatkan efektivitas masing-masing larutan kumur yang dipakai dalam penelitian ini, yaitu klorheksidin dan larutan teh hijau. Terlihat adanya pengurangan jumlah koloni Streptococcus mutans mulai dari sebelum intervensi, 15 menit setelah intervensi, dan akhirnya 30 menit setelah intervensi. Hal ini berlaku pada masing-masing obat kumur, baik klorheksidin maupun teh hijau. Berdasarkan hasil uji ANOVA, diperoleh nilai $p=0.000(p<0.05)$ pada kedua kelompok. Hal ini menunjukkan penurunan yang dihasilkan oleh masing-masing obat kumur merupakan penurunan yang signifikan.

Tabel 3 menunjukkan hasil uji beda lanjut jumlah koloni Streptococcus mutans berdasarkan interval waktu setelah berkumur dengan klorheksidin dan larutan teh hijau. Tabel ini merupakan hasil uji beda lanjut setelah uji ANOVA menyatakan perbedaan yang signifikan. 
Tabel 3. Hasil uji beda lanjut jumlah koloni Streptococcus mutans berdasarkan interval waktu setelah berkumur dengan klorheksidin dan larutan teh hijau

\begin{tabular}{lllll}
\hline $\begin{array}{l}\text { Kelompok } \\
\text { Obat Kumur }\end{array}$ & $\begin{array}{l}\text { CFU } \\
\text { S.mutans }\end{array}$ & Pembanding & $\begin{array}{l}\text { Mean } \\
\text { Difference }\end{array}$ & p-value \\
\hline Klorheksidin & $\begin{array}{l}\text { CFU } \\
\text { pretest }\end{array}$ & $\begin{array}{l}\text { CFU 15 } \\
\text { menit }\end{array}$ & 41,767 & $0,000^{*}$ \\
& & $\begin{array}{l}\text { CFU 30 } \\
\text { menit }\end{array}$ & 71,100 & $0,000^{*}$ \\
& $\begin{array}{l}\text { CFU 15 } \\
\text { menit }\end{array}$ & $\begin{array}{l}\text { CFU 30 } \\
\text { menit }\end{array}$ & 29,333 & $0,000^{*}$ \\
Larutan teh & $\begin{array}{l}\text { CFU } \\
\text { pretest }\end{array}$ & $\begin{array}{l}\text { CFU 15 } \\
\text { menit }\end{array}$ & 41,367 & $0,000^{*}$ \\
& $\begin{array}{l}\text { CFU 30 } \\
\text { menit }\end{array}$ & 68,067 & $0,000^{*}$ \\
& $\begin{array}{l}\text { CFU 15 } \\
\text { menit }\end{array}$ & $\begin{array}{l}\text { CFU 30 } \\
\text { menit }\end{array}$ & 26,700 & $0,000^{*}$ \\
\hline
\end{tabular}

*Post Hoc Test: Least Significant Difference (LSD) test: $p<0,05$

Pada tabel ini, dipaparkan perbedaan masing-masing jumlah koloni bakteri berdasarkan interval waktu. Terlihat bahwa penurunan jumlah koloni berdasarkan interval waktu seluruhnya menunjukkan hasil yang signifikan.

Tabel 3 menunjukkan perbedaan efektivitas klorheksidin dan larutan teh hijau pada interval waktu 15 menit dan 30 menit setelah berkumur. Setelah secara individual, dinyatakan bahwa klorheksidin dan larutan teh hijau efektif mengurangi jumlah koloni Streptococcus mutans, maka pada tabel ini akan dibandingkan kedua larutan tersebut, yang mana yang lebih baik dalam mengurangi jumlah koloni Streptococcus mutans. Terlihat pada tabel 3, setelah berkumur dengan klorheksidin dan larutan teh hijau, pada menit ke-15 penurunan yang dihasilkan kedua obat kumur ini hampir sama banyak. Pada kelompok klorheksidin, jumlah koloni menurun hingga 43,80CFU/ml, sedangkan pada kelompok teh hijau jumlah koloni menurun hingga 44,20CFU/ml. Hanya terdapat perbedaan $0,40 \mathrm{CFU} / \mathrm{ml}$. Berdasarkan hasil uji statistik, diperoleh $\mathrm{p}=0,061(\mathrm{p}>0,05)$, artinya bahwa perbedaan ini tidak signifikan dan dapat dianggap sama. Adapun, setelah 30 menit, klorheksidin berhasil mengurangi jumlah koloni Streptococcus mutans menjadi 14,47; sedangkan pada larutan teh hijau hanya berkurang hingga 17,50 . Terdapat perbedaan hingga $3 \mathrm{CFU} / \mathrm{ml}$ pada waktu 30 menit setelah berkumur. Berdasarkan hasil uji statistik, diperoleh nilai $p=0,656(p>0,05)$, yang berarti bahwa tidak terdapat perbedaan jumlah koloni Streptococcus mutans yang signifikan antara obat kumur klorheksidin dan larutan teh hijau pada interval waktu 30 menit setelah berkumur. Namun, penurunan klorheksidin lebih besar dibandingkan teh hijau.

\section{PEMBAHASAN}

Penelitian mengenai perbedaan efektivitas antara klorheksidin dan larutan teh hijau telah dilakukan. Teh hijau kemasan merk Tong $\mathrm{Tji}^{\circledR}$ dipilih sebagai bahan penelitian karena memiliki kadar polifenol tertinggi dari beberapa jenis teh hijau lainnya yang beredar di pasaran. Sedangkan klorheksidin dipilih sebagai pembanding karena merupakan obat kumur gold standard yang paling efektif dalam mengurangi jumlah koloni Streptococcus mutans. ${ }^{7,12}$

Berdasarkan hasil penelitian, terdapat efektivitas yang signifikan terhadap penurunan jumlah koloni Streptococcus mutans berdasarkan interval waktu pada kedua jenis bahan tersebut. Hal ini menunjukkan bahwa ada pengurangan jumlah koloni Streptococcus mutans yang berarti setelah berkumur dengan klorheksidin dan larutan teh hijau tersebut selama 3 detik dan pengambilan sampel saliva pada menit ke 15 dan menit ke 30 dengan kedua agen antimikroba tersebut. Diambil waktu 15 dan 30 menit karena 15 menit merupakan waktu obat kumur sudah bekerja secara efektif, dan 30 menit untuk melihat seberapa besar penurunan yang terjadi dari selang waktu 15 menit ke 30 menit. Hal ini dapat dilihat dari adanya fenomena yang sama dari kedua jenis bahan tersebut, dengan adanya penurunan tingkat koloni Streptococcus mutans setelah berkumur baik dengan klorheksidin maupun larutan teh hijau pada menit ke-15 dan 30.

Efektivitas tersebut sesuai dengan penelitian-penelitian sebelumnya yang menunjukkan penurunan jumlah bakteri Streptococcus mutans setelah berkumur larutan teh hijau. Kandungan polifenol teh hijau, terutama katekin dapat menghambat pertumbuhan bakteri dengan merusak dinding sel bakteri. Konsentrasi hambat minimal larutan teh hijau menurut Wijaya dan Samad adalah 2,5\%, sesuai dengan konsentrasi larutan teh hijau yang digunakan dalam penelitian ini. Konsentrasi ini menunjukkan aktivitas antibakteri yang signifikan terhadap Streptococcus mutans. Awadalla, et al, melaporkan bahwa berkumur dengan larutan teh hijau tanpa gula sangat menghambat pertumbuhan Streptococcus mutans pada plak dan saliva yang merupakan bakteri utama penyebab terjadinya karies gigi. Tehrani mengemukakan bahwa larutan teh hijau memperlihatkan penurunan Streptococcus mutans dan Lactobacillus pada saliva anak yang lebih signifikan dibandingkan larutan kumur sodium fluoride. ${ }^{8,11,13}$

Polifenol yang terkandung dalam teh hijau bersifat desinfektan, antiseptik, serta mampu menghambat pertumbuhan mikroorganisme, karena polifenol mempunyai kemampuan denaturasi protein sel mikroorganisme dan merusak membran sel mikroorganisme. Selain itu, komponen bioaktif dari teh hijau mampu mempengaruhi proses terjadinya karies gigi dengan menghambat kerja enzim 
glukosiltransferase (GTF) sehingga mengganggu proses perlekatan bakteri ke email. ${ }^{8,14}$

Efektivitas klorheksidin dalam menurunkan jumlah koloni Streptococcus mutans juga sejalan dengan penelitian sebelumnya oleh Neeraja yang menyatakan bahwa klorheksidin dapat menurunkan jumlah koloni bakteri Streptococcus mutans pada plak dan saliva. Klorheksidin mengikat baik terhadap seluruh struktur permukaan. Ketika klorheksidin mengikat dinding sel permukaan, akan meningkatkan permeabilitas sel sehingga akan mengakibatkan rupturnya membran sel, mengarah pada ketidakseimbangan osmotik dengan penetrasi ke dalam sitoplasma sehingga mengakibatkan kematian sel. ${ }^{4,5}$

Hasil penelitian juga menunjukkan adanya perbedaan efektivitas klorheksidin dan larutan teh hijau pada interval waktu 15 menit dan 30 menit setelah berkumur, hal ini menunjukkan bahwa tidak terdapat perbedaan yang berarti antara obat kumur klorheksidin dan larutan teh hijau terhadap penurunan tingkat koloni Streptococcus mutans pada menit ke-15 dan 30 setelah berkumur. Dengan demikian terlihat pada penelitian ini bahwa kedua bahan efektif dalam menurunkan jumlah koloni Streptococcus mutans, namun klorheksidin menunjukkan penurunan yang lebih besar dibandingkan teh hijau pada interval waktu 15 dan 30 menit setelah berkumur pada saliva anak usia 6-12 tahun. Namun tidak terdapat perbedaan yang berarti antara klorheksidin dan larutan teh hijau pada menit ke-15 dan 30 setelah berkumur. Perlu diingat bahwa klorheksidin merupakan bahan kimia yang dapat menyebabkan rasa tidak enak dan stain pada gigi, sedangkan larutan teh hijau merupakan bahan alami yang lebih aman untuk anak-anak. Sejalan dengan penelitian Moghbel et al yang dikutip oleh Kukreja bahwa larutan teh hijau terbukti aman untuk anak-anak dan wanita hamil..$^{15,16}$

\section{SIMPULAN}

Simpulan dari penelitian ini adalah tidak terdapat perbedaan efektivitas yang berarti antara klorheksidin dan larutan teh hijau terhadap jumlah koloni Streptococcus mutans pada saliva anak usia 6-12 tahun. Pemanfaatan teh hijau berdasarkan penelitian ini diperlukan kerja sama dengan pihak farmasi untuk dibuatkan formula yang lebih baik dengan tidak mengurangi kadar zat aktif didalam teh hijau sehingga lebih mudah, murah dan aman untuk digunakan seharihari. Perlu diingat bahwa klorhexidin merupakan bahan kimia yang dapat menyebabkan rasa tidak enak dan stain pada gigi, sedangkan larutan teh hijau merupakan bahan alami yang lebih aman untuk anak-anak

\section{UCAPAN TERIMA KASIH}

Ucapan terimakasih kepada Prof.DR.drg. Burhanuddin Passiga, M.Kes.

\section{DAFTAR PUSTAKA}

1. Roberson TM, Heymann HO, Swift EJ. Sturdevant's art \& science of operative dentistry. 4th ed. Copenhagen: Mosby; 2002.

2. Tedjosasongko U, Pradopo S, Nuraini P. Perubahan oral flora dan sensitifitas karies gigi anak setelah pengulasan fluoride secara topikal. J Penelititian Medik Eksakta. 2008;7:9. Indonesian.

3. Darwita RR, Novrinda H, Budiharto, Pratiwi PD, Amalia R, et al. Efektivitas program sikat gigi bersama terhadap risiko karies gigi pada murid Sekolah Dasar. J Indonesian Med Assoc. 2011;61:204-9. Indonesian.

4. Neeraja R, Anantharaj A, Praveen P, Karthik V, Vinitha M. The effect of povidone-iodine and chlorhexidine mouth rinses on plaque Streptococcus mutans in 6-12 year-old school children. J Indian Soc Period Pedod Prevent Dent. 2008:14-8.

5. Cooper R. A review of the evidence for the use of topical antimicrobial agents in wound care [Internet] 2004. [cited 2012, Dec 16] Available from: http:// www.worldwidewounds.com/2004/february/ Cooper/Topical-Antimicrobial-Agents.html.

6. Kocak MM, Ozcan S, Kocak S, Topuz O, Erten $\mathrm{H}$. Comparison of the efficacy of three different mouthrinse solutions in decreasing the level of Streptococcus mutans in saliva. Eur J Dent. 2009;3:57-61.

7. Gupta N, Bhat M. Comparative evaluation of 0.2 $\%$ chlorhexidine and magnetized water as a mouth rinse on Streptococcus mutans in children. Int J Clin Pediatric Dent. 2011; 4:190-4.

8. Tehrani MH, Asghari G, Hajiahmadi M. Comparing Streptococcus mutans and Lactobacillus colony count changes following green tea mouth rinse or sodium fluoride mouth rinse use in children. Dent Res J. 2011;8:58-63.

9. Arab A, Maroofian A, Golestani S, Shafaee H, Sohrabi K, et al. Review of the therapeutic effects of Camellia sinensis (green tea) on oral and periodontal health. J Med Plants Res. 2011;5:54649.

10. Cabrera C, Artacho R, Gimenez R. Beneficial effects of green tea. J Am Coll Nutr. 2006; 25:7999.

11. Wijaya D, Samad R. Daya hambat teh hitam, teh hijau, dan teh golong terhadap pertumbuhan Streptococcus mutans. Jurnal PDGI. 2005:82-7. Indonesian. 
12. Desvina ML, Johan A. Perbandingan kadar polifenol seduhan teh hijau pada berbagai merk teh hijau [thesis]. Semarang. Fakultas Kedokteran Universitas Diponegoro, 2007. Indonesian.

13. Awadalla HI, Ragab MH, Bassuoni MW, Fayed MT, Abbas MO. A pilot study of the role of green tea use on oral health. Int J Dent Hyg. 2011;9:110-6.

14. Oktanauli P, Nuning F, Lidiawati. Efek antimikroba polifenol teh hijau terhadap Streptococcus mutans. JITEKGI. 2011;8:19-23. Indonesian.

15. Kukreja BJ, Dodwad V. Herbal mouthwashes-a gift of nature. Int J Pharm Bioscience. 2012;3:46-52.

16. Bajaj N, Tandon S. The effect of Triphala and Chlorhexidine mouthwash on dental plaque, gingival inflammation, and microbial growth. Int J Ayurverda. 2011;2:29-36. 